\title{
Optimization of the Production Process of Enzymatic Activity of Lentinula edodes (Berk.) Pegler in Holocelulases
}

\author{
Juliane Andressa Chicatto1, Vitória Arend Castamann1, Cristiane Vieira Helm², \\ Lorena Benathar Ballod Tavares ${ }^{1}$ \\ ${ }^{1}$ Regional University of Blumenau-FURB, Blumenau, Brazil \\ ${ }^{2}$ Brazilian Agricultural Research Corporation, Research Center of Forestry-EMBRAPA, Colombo, Brazil \\ Email: julianechicatto@hotmail.com
}

Received 17 December 2013; revised 6 February 2014; accepted 3 March 2014

Copyright (C) 2014 by authors and Scientific Research Publishing Inc.

This work is licensed under the Creative Commons Attribution International License (CC BY). http://creativecommons.org/licenses/by/4.0/

\section{Open Access}

\begin{abstract}
Issues such as fossil fuels and oil supplies have stimulated the search for renewable alternatives such as biofuels. Agricultural crop residues represent an abundant renewable resource for the future of bioethanol. For it to be a viable alternative, the second-generation ethanol which ought to provide a net energy gain, environmental benefits, should be economically viable, and also be produced in large quantities without reducing food supplies. The current difficulty of lignocellulosic biofuel production is the hydrolysis of biomass into sugar. This is a work in which the white-rot Lentinula edodes fungus secretes substantial amounts of hydrolytic enzymes and is useful for degradation of lignocellulosic biomass which have not been described yet. The objective of this investigation was to evaluate the $\mathrm{pH}$ effect $(5,6$ and 7$)$, agitation $(0,100 \mathrm{rpm}$ and $200 \mathrm{rpm})$ and also the cultivation time (6, 9 and 12 days). The culture medium was supplemented with agro-industrial residue and the EF 52 strain of the fungus Lentinula edodes was used as a processing agent. A factorial design $2^{2}$ repeating the central point was performed. Submerged cultivation was conducted in a synthetic medium and was incubated at $25^{\circ} \mathrm{C}$. The total protein content was determined as well as the activity of xylanase and cellulase (endoglucanase, exoglucanase and $\beta$-glucosidase). By Pareto diagram, the agitation and $\mathrm{pH}$ variables were significant for enzymatic activities. The highest enzyme expression occurred at $\mathrm{pH}$ values between 5.0 and 6.0 and above $100 \mathrm{rpm}$ agitation. The exoglucanase was the enzyme which showed the highest activity in terms of cellulases, despite the cultivation time. Regarding the production of other enzymes and proteins, the most significant cultivation time was 12 days.
\end{abstract}

\section{Keywords}

Bioethanol, Cellulase, Xylanase, Enzymatic Hydrolysis, Basidiomycetes 


\section{Introduction}

Agricultural residues represent great potential in biotechnological resources, mainly due to its low cost, accessibility and compositions of nutrients like carbon, nitrogen and mineral processes. It has been of economic interest to countries with abundant biomass and agro-industrial residues [1]. If appropriate technology is employed, this material can be converted into commercial products or raw materials for secondary processes [2].

The lignocellulosic residues are the most abundant in the world and such biomass is huge potential for obtaining products of industrial interest such as glucose, ethanol and protein biomass [3].

The production of bioethanol processing of raw material in alcohol therefore called second generation ethanol process, is made by micro-organisms through anaerobic fermentation of sugar, producing ethanol and $\mathrm{CO}_{2}$ as waste products [4].

The second generation bioethanol produced from lignocellulosic materials is one of the most promising renewable energy resources. Bagasse is specifically a raw material of particular interest since it represents a waste in large quantities in Brazil for being readily available and for having low agricultural value. Current costs of enzymatic saccharification are among the largest contributors to the total production cost of lignocellulosic ethanol. A major challenge is to develop efficient and economically viable step [5].

For the bioconversion of lignocellulose biomass to ethanol there is the necessity of enzymes being those produced by fungi or bacteria [6]. The conversion processes are currently based on empirical knowledge, requiring further studies on the factors involved in the enzymatic hydrolysis of cellulose, such as: biomass characteristics, the optimization of pre-treatment as well as enzymatic activity and their mechanisms of action [7].

Filamentous fungi are particularly interesting due to the production of extracellular enzymes, which are of great technological potential [8]. Thus, the fungus Lentinula edodes (Figure 1) has recognized economic importance. However, as a white rot fungus, they are also capable of degrading plant material rich in lignin and cellulose, shared with other white rot fungi, which is of great interest to the paper industry and biofuel future.

The cellulase secreted by these fungi is formed by three main components: exoglucanases or cellobiohydrolases, endoglucanases or celodextrinases, and celobiases or $\beta$-glucosidases, being the last one not considered legitimate cellulases, but playing an important role in the hydrolysis of cellulose. For the hydrolysis of cellulose, the joint action of endo-exo enzymes occurs as follows: exoglucanases work as exoenzymes that act at the end of the chains and release cellobiose as the main product; endoglucanases act randomly along the chain and produce new sites for action of exoglucanases, and $\beta$-glucosidases complete the process by the hydrolysis of cellobiose and other short oligosaccharides glucose [9].

The xylanases have a major role in the hydrolysis of sugarcane bagasse by hydrolyzing xylan, polysaccharide composed of xylose monomer units, which is a major constituent of hemicellulose [10] [11]. Hemicellulases are glycosides which catalyze the hydrolysis of polysaccharides in a synergistic action and cellulases promote the hydrolysis of sugarcane bagasse more efficiently than classes of enzymes alone [12].

The use of bagasse of sugarcane can become viable and reduce the cost of cellulase and xylanase production.

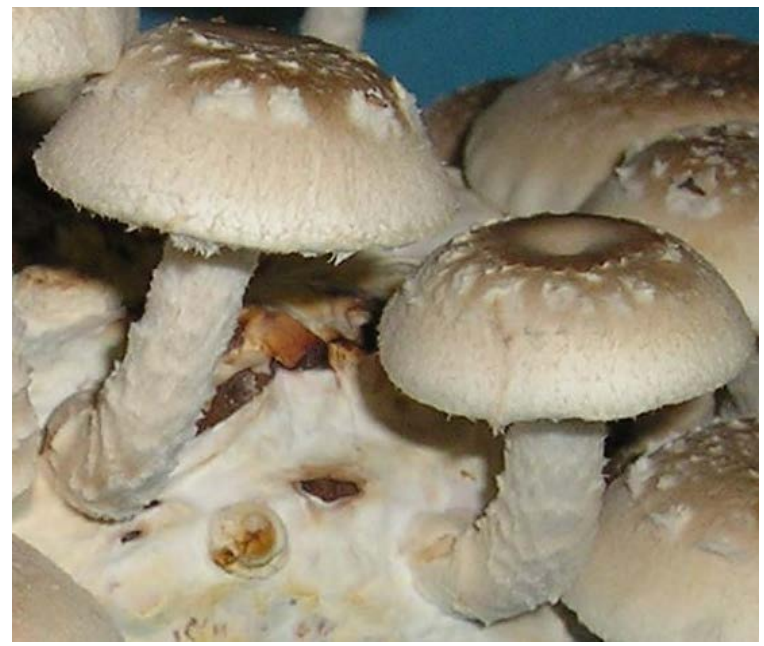

Figure 1. Lentinula edodes EF lineage. 
However, the operating conditions for the fermentation need to be optimized for maximum production in industrial technology.

The classic method of optimization is to change a particular variable and fixed to maintain the other, which is cumbersome, time consuming, especially when one considers a large number of variables, it may lead to unreliable results and inaccurate conclusions. These limitations can be overcome with the use of factorial design, which allows the simultaneous consideration of the factors' effects, which optimizes the enzyme activity and allows the achievement of a minimum number of experiments [13] [14].

Thus, factorial designs have been used as reliable for the study of the influence of multiple factors in the production of enzymes techniques [15].

The objective of this study was to determine variables which influence the simultaneous production of cellulase and xylanase by Lentinula edodes strain EF 52 using bagasse sugarcane as a substrate by means of factorial design and submerged cultivation medium.

\section{Material and Methods}

\subsection{Microorganism}

The microorganism used in the experiment was the basidiomycete fungus Lentinula edodes (isolated EF 52) Collection of Work Technology Laboratory Non-timber Forest Products of the Brazilian Agricultural Research Corporation-National Research Center of Forestry—EMBRAPA (Colombo, PR, Brazil). The experiment was conducted at the Laboratory of Biochemical Engineering at the Universidade Regional de Blumenau (FURB), SC, Brazil, where the isolates were grown and maintained in Petri dishes containing Potato Dextrose Agar (PDA) for seven days in an environmental chamber at $25^{\circ} \mathrm{C}$ in the absence light and after growth, stored at $4^{\circ} \mathrm{C}$.

\subsection{Enzyme Production}

For the production of enzymes by submerged fermentation, the proposed synthetic medium [16] composed of $0.68 \mathrm{~g} \cdot \mathrm{L}^{-1}$ potassium phosphate $\left(\mathrm{KH}_{2} \mathrm{PO}_{4}\right), 0.87 \mathrm{~g} \cdot \mathrm{L}^{-1}$, potassium phosphate $\left(\mathrm{K}_{2} \mathrm{HPO}_{4}\right), 0.2 \mathrm{~g} \cdot \mathrm{L}^{-1}$ of magnesium sulphate $\left(\mathrm{MgSO}_{4}-7 \mathrm{H}_{2} \mathrm{O}\right), 0.2 \mathrm{~g} \cdot \mathrm{L}^{-1}$ of calcium chloride $\left(\mathrm{CaCl}_{2}\right), 2 \times 10^{-3} \mathrm{~g} \cdot \mathrm{L}^{-1}$ of zinc sulphate $\left(\mathrm{ZnSO}_{4}\right), 2 \times$ $10^{-3} \mathrm{~g} \cdot \mathrm{L}^{-1}$ of ferrous sulfate $\left(\mathrm{FeSO}_{4}\right), 2 \times 10^{-3} \mathrm{~g} \cdot \mathrm{L}^{-1}$ of manganese sulfate $\left(\mathrm{MnSO}_{4}\right)$ were used.

In synthetic medium supplementation with a nitrogen source, ammonium sulfate $0.1 \mathrm{~g} \cdot \mathrm{L}^{-1}$ and a carbon source was performed. Was also used agroindustrial residue of sugarcane bagasse to an amount of $30 \mathrm{~g} \cdot \mathrm{L}^{-1}$ [17]. The residue was washed several times with distilled water, dried in an oven at $60^{\circ} \mathrm{C}$ for 40 hours and chopped in a wiley mill to a particle size of $2 \mathrm{~mm}$. The experimental design was a factorial analysis to $2^{2}$ with the center point replicated as shown in Table 1. Response variables as the amount of protein, the activity of xylanase, endoglucanase, exoglucanase and $\beta$-glucosidase were determined by response surface methodology (RSM) by Statistic software 7.0.

In the independent variables, samples were collected on days 6, 9 and 12.

The submerged fermentations were performed in $250 \mathrm{ml}$ Erlenmeyer flasks containing $150 \mathrm{ml}$ of culture medium. The flasks were closed with cotton gauze wrapped and autoclaved at $121^{\circ} \mathrm{C}$ for 15 minutes. The culture medium with five $L$. edodes pellets remained at $25^{\circ} \mathrm{C}$, with different $\mathrm{pH}$ and agitation until the twelfth day.

\subsection{Enzymatic Activities}

The extraction of the enzyme complex was performed by vacuum filtration. The extracts were centrifuged and stored at $4^{\circ} \mathrm{C}$. The xylanase activities were determined by the amount of reducing sugars released from xylan

Table 1. Independent variables, levels and actual values used in the factorial design to study the production of enzymes and proteins.

\begin{tabular}{cccc}
\hline & \multicolumn{2}{c}{ Levels } \\
Independent variables & -1 & 0 & 1 \\
\cline { 2 - 4 } $\mathrm{pH}$ & 5 & 6 & 7 \\
Agitation (rpm) & 0 & 100 & 200 \\
\hline
\end{tabular}


from birchwood [18]. The enzymatic assay was performed using $0.9 \mathrm{ml}$ of $1 \%$ xylan and $0.1 \mathrm{ml}$ enzyme extract, after 5 minutes of reaction the reducing sugars were determined using 3.5 dinitrosalicylic (DNS) [19].

The activities of endoglucanase and exoglucanase were determined according to the method described by Tanaka [20]. This method consists in conducting the hydrolysis of a $0.44 \%$ solution of carboxymethylcellulose in sodium acetate buffer $0.05 \mathrm{M} \mathrm{pH} 5.0$ to carboxymethylcellulase activity of the fraction, and a $1.1 \%$ suspension in the same buffer, microcrystalline cellulose (Avicel) to avicelase fraction. The reaction was initiated by adding $0.9 \mathrm{ml}$ enzyme extract in $1 \mathrm{~mL}$ of Avicel solution to determine the exoglucanase and $1 \mathrm{~mL}$ of the CMC solution to determine the endoglucanase. The amount of reducing sugars was determined by the DNS method [19].

The activity of $\beta$-glucosidase or cellobiose was determined according to Wood and Garcia-Campayo [21]. Where $1 \mathrm{~mL}$ of cellobiose, $0.53 \%$ (diluted in sodium acetate $\mathrm{pH}$ 5.0) was added to $1 \mathrm{~mL}$ enzyme and incubated at $50^{\circ} \mathrm{C}$ for 30 minutes extract. The reaction was stopped by immersing the tubes in boiling water for 5 minutes. After transfer to cold water bath, the glucose produced was determined based on the reaction of glucose oxidaseperoxidase kit using God-Pod.

For all of the enzymatic assays one unit of enzyme activity (U) was defined as the amount of enzyme which will liberate one $\mu \mathrm{mol}$ reducing sugars (glucose or xylose) per minute at $50^{\circ} \mathrm{C}$ and the enzyme activity expressed in $\mathrm{UI} \cdot \mathrm{L}^{-1}\left(\mathrm{U}=\mu \mathrm{mol} \cdot \mathrm{mL}^{-1} \cdot \mathrm{min}^{-1}\right)$. The level of significance for studies of protein production and the study of culture conditions showed a $95 \%$ confidence. To validate models analysis of variance was used, checking the coefficient of determination $\left(\mathrm{R}^{2}\right)$.

\subsection{Total Protein}

A volume of $20 \mu \mathrm{L}$ of each extracts in a test tube and $1 \mathrm{~mL}$ of Bradford reagent was added [22]. After two minutes the reading was done in a spectrophotometer (Shimadzu UV-1650). The blank was made with $20 \mu \mathrm{L}$ of water and $1 \mathrm{~mL}$ of Bradford reagent. To determine the protein concentration of the extracts, the same procedures were made selecting the standard curve used. The result is given in $\mathrm{mg} \cdot \mathrm{mL}^{-1}$.

\section{Results and Discussion}

According to the experimental data of Table 2, the exoglucanase showed the highest enzyme activities, compared to certain other enzymes. This enzyme variation between values of enzyme activity was $52 \%\left(7.97 \mathrm{UI} \cdot \mathrm{L}^{-1}\right.$ to $4.17 \mathrm{UI} \cdot \mathrm{L}^{-1}$ ), however, the values of enzyme activity were similar for all three periods $\left(5.7 \mathrm{UI} \cdot \mathrm{L}^{-1}\right.$ ), not considering the process variables ( $\mathrm{pH}$ and agitation).

The same was observed for $\beta$-glucosidase $\left(0.074 \mathrm{UI} \cdot \mathrm{L}^{-1}\right)$ and endoglucanase $\left(0.43 \mathrm{UI} \cdot \mathrm{L}^{-1}\right)$, except for the period, which was reduced by over $60 \%$ with nine days. For xylanase, the average values of the activities were gradually increasing with time ( 6 days $=0.15 \mathrm{UI} \cdot \mathrm{L}^{-1}, 9$ days $=0.19 \mathrm{UI} \cdot \mathrm{L}^{-1}$ and 12 days $\left.=0.28 \mathrm{UI} \cdot \mathrm{L}^{-1}\right)$.

Table 3 shows the effect of the variables on the production of enzymes and proteins. All factors; $\mathrm{pH}$, agitation and the interaction between them were statistically significant in the enzyme production somehow. The negative effect indicates an increase of this variable would lead to a decreased production of enzymes.

It was found employing the response surface methodology that with 12 days of cultivation, had the highest production of xylanase enzyme, $0.90 \mathrm{UI} \cdot \mathrm{L}^{-1}$ (Figure 2). However, this was a really isolated situation, indicating a possible experimental problem because all other treatments showed that agitation is positive for increased enzyme activity, particularly at $\mathrm{pH}$ values between 5.0 and 6.0 and agitation between 100 and $200 \mathrm{rpm}$.

Other works with Acremonium sp. EAO810 fungus [23] also found the xylanase as a basic protein as there was substantial activity in the $\mathrm{pH}$ range 4.5 - 8.0, with a maximum activity obtained at $\mathrm{pH}$ 6.4. Nevertheless, some other studies [24] found higher values $\left(0.30 \mathrm{UI} \cdot \mathrm{L}^{-1}\right)$ at the highest level of variable agitation $(180 \mathrm{rpm})$.

The change of $\mathrm{pH}$ and temperature can improve the production of xylanase considerably [25].

The endoglucanase had higher enzyme activity at $\mathrm{pH}$ values above 6.0 and with no stirring, at 12 days of cultivation. The values of $\mathrm{pH}$ and agitation showed wide range of reaction (Figure 3). On the other hand, with 9 days of cultivation the enzyme activity was still below the expected value (Figure 4).

The highest activity was $1.01 \mathrm{UI} \cdot \mathrm{L}^{-1}$. Conversely, [24] found values of $0.006 \mathrm{UI} \cdot \mathrm{L}^{-1}$ in higher levels of agitation, $180 \mathrm{rpm}$ and culturing for 7 days.

Working with $L$. edodes [26] on solid state fermentation with substrate of wheat straw, the authors found low production values of endoglucanase enzyme, $0.8 \mathrm{U} \cdot \mathrm{g}^{-1}$ and [27] [28] in medium supplemented with eucalyptus residues also found low values. 
Table 2. Experimental results in terms of enzymatic activities and proteins in relation to different values of pH and agitation.

\begin{tabular}{|c|c|c|c|c|c|c|c|}
\hline \multirow[b]{2}{*}{ Essay } & \multirow[b]{2}{*}{$\begin{array}{l}\text { Agitation } \\
\text { (rpm) }\end{array}$} & \multirow[b]{2}{*}{$\mathrm{pH}$} & \multicolumn{5}{|c|}{ Cultivation time: 6 days } \\
\hline & & & $\begin{array}{l}\beta \text {-glucosidase } \\
\left(\mathrm{UI} \cdot \mathrm{L}^{-1}\right)\end{array}$ & $\begin{array}{l}\text { Endoglucanase } \\
\left(\mathrm{UI} \cdot \mathrm{L}^{-1}\right)\end{array}$ & $\begin{array}{l}\text { Exoglucanase } \\
\left(\mathrm{UI}^{-L^{-1}}\right)\end{array}$ & $\begin{array}{c}\text { Xylanase } \\
\left(\mathrm{UI} \cdot \mathrm{L}^{-1}\right)\end{array}$ & $\begin{array}{l}\text { Proteins } \\
\left(\mathrm{mg} \cdot \mathrm{mL}^{-1}\right)\end{array}$ \\
\hline 1 & $-1(0)$ & $-1(5)$ & 0.06 & 0.75 & 5.12 & 0.08 & 1.61 \\
\hline 2 & $-1(0)$ & $0(6)$ & 0.08 & 0.38 & 4.99 & 0.23 & 1.57 \\
\hline 3 & $-1(0)$ & $+1(7)$ & 0.26 & 0.45 & 6.11 & 0.03 & 1.65 \\
\hline 4 & $0(100)$ & $-1(5)$ & 0.08 & 0.55 & 6.16 & 0.11 & 1.72 \\
\hline 5 & $0(100)$ & $0(6)$ & 0.02 & 0.42 & 5.68 & 0.35 & 1.70 \\
\hline 6 & $0(100)$ & $0(6)$ & 0.06 & 0.38 & 6.01 & 0.11 & 1.83 \\
\hline 7 & $0(100)$ & $0(6)$ & 0.07 & 0.36 & 6.23 & 0.11 & 1.74 \\
\hline 8 & $0(100)$ & $+1(7)$ & 0.06 & 0.53 & 6.01 & 0.15 & 1.75 \\
\hline 9 & $+1(200)$ & $-1(5)$ & 0.12 & 0.27 & 5.65 & 0.12 & 1.72 \\
\hline 10 & $+1(200)$ & $0(6)$ & 0.09 & 0.28 & 6.18 & 0.39 & 1.81 \\
\hline \multirow[t]{2}{*}{11} & $+1(200)$ & $+1(7)$ & 0.04 & 0.51 & 5.36 & 0.07 & 1.78 \\
\hline & & & \multicolumn{5}{|c|}{ Cultivation time: 9 days } \\
\hline Essay & $\begin{array}{l}\text { Agitation } \\
\text { (rpm) }\end{array}$ & $\mathrm{pH}$ & $\begin{array}{l}\beta \text {-glucosidase } \\
\left(\mathrm{UI} \cdot \mathrm{L}^{-1}\right)\end{array}$ & $\begin{array}{l}\text { Endoglucanase } \\
\left(\mathrm{UI} \cdot \mathrm{L}^{-1}\right)\end{array}$ & $\begin{array}{l}\text { Exoglucanase } \\
\left(\mathrm{UI} \cdot \mathrm{L}^{-1}\right)\end{array}$ & $\begin{array}{l}\text { Xylanase } \\
\left(\mathrm{UI} \cdot \mathrm{L}^{-1}\right)\end{array}$ & $\begin{array}{l}\text { Proteins } \\
\left(\mathrm{mg} \cdot \mathrm{mL}^{-1}\right)\end{array}$ \\
\hline 1 & $-1(0)$ & $-1(5)$ & 0.08 & 0.26 & 5.32 & 0.24 & 1.92 \\
\hline 2 & $-1(0)$ & $0(6)$ & 0.07 & 0.45 & 5.77 & 0.19 & 1.85 \\
\hline 3 & $-1(0)$ & $+1(7)$ & 0.04 & 0.23 & 5.74 & 0.15 & 1.82 \\
\hline 4 & $0(100)$ & $-1(5)$ & 0.05 & 0.37 & 4.98 & 0.16 & 1.80 \\
\hline 5 & $0(100)$ & $0(6)$ & 0.06 & 0.35 & 6.65 & 0.14 & 1.80 \\
\hline 6 & $0(100)$ & $0(6)$ & 0.05 & 0.31 & 5.69 & 0.39 & 1.81 \\
\hline 7 & $0(100)$ & $0(6)$ & 0.04 & 0.29 & 2.39 & 0.22 & 1.73 \\
\hline 8 & $0(100)$ & $+1(7)$ & 0.09 & 0.31 & 4.80 & 0.21 & 1.83 \\
\hline 9 & $+1(200)$ & $-1(5)$ & 0.09 & 0.11 & 7.97 & 0.33 & 1.84 \\
\hline 10 & $+1(200)$ & $0(6)$ & 0.10 & 0.29 & 6.02 & 0.04 & 1.82 \\
\hline \multirow[t]{2}{*}{11} & $+1(200)$ & $+1(7)$ & 0.07 & 0.17 & 5.95 & 0.08 & 1.90 \\
\hline & & & \multicolumn{5}{|c|}{ Cultivation time: 12 days } \\
\hline Essay & $\begin{array}{l}\text { Agitation } \\
\text { (rpm) }\end{array}$ & $\mathrm{pH}$ & $\begin{array}{l}\beta \text {-glucosidase } \\
\left(\mathrm{UI} \cdot \mathrm{L}^{-1}\right)\end{array}$ & $\begin{array}{l}\text { Endoglucanase } \\
\left(\mathrm{UI} \cdot \mathrm{L}^{-1}\right)\end{array}$ & $\begin{array}{l}\text { Exoglucanase } \\
\left(\mathrm{UI} \cdot \mathrm{L}^{-1}\right)\end{array}$ & $\begin{array}{c}\text { Xylanase } \\
\left(\mathrm{UI} \cdot \mathrm{L}^{-1}\right)\end{array}$ & $\begin{array}{l}\text { Proteins } \\
\left(\mathrm{mg} \cdot \mathrm{mL}^{-1}\right)\end{array}$ \\
\hline 1 & $-1(0)$ & $-1(5)$ & 0.11 & 0.29 & 5.70 & 0.34 & 1.92 \\
\hline 2 & $-1(0)$ & $0(6)$ & 0.07 & 0.31 & 5.72 & 0.00 & 1.88 \\
\hline 3 & $-1(0)$ & $+1(7)$ & 0.06 & 1.01 & 6.40 & 0.90 & 1.94 \\
\hline 4 & $0(100)$ & $-1(5)$ & 0.09 & 0.29 & 5.89 & 0.23 & 1.86 \\
\hline 5 & $0(100)$ & $0(6)$ & 0.09 & 0.31 & 5.71 & 0.07 & 1.93 \\
\hline 6 & $0(100)$ & $0(6)$ & 0.05 & 0.38 & 6.26 & 0.17 & 1.93 \\
\hline 7 & $0(100)$ & $0(6)$ & 0.07 & 0.22 & 6.53 & 0.16 & 2.05 \\
\hline 8 & $0(100)$ & $+1(7)$ & 0.09 & 0.54 & 6.00 & 0.10 & 2.01 \\
\hline 9 & $+1(200)$ & $-1(5)$ & 0.07 & 0.43 & 4.17 & 0.50 & 2.00 \\
\hline 10 & $+1(200)$ & $0(6)$ & 0.07 & 0.46 & 6.25 & 0.42 & 2.00 \\
\hline 11 & $+1(200)$ & $+1(7)$ & 0.01 & 0.46 & 4.23 & 0.27 & 1.93 \\
\hline
\end{tabular}

Elisashvilli et al., [29] cite it is already known that the type and composition of the lignocellulosic substrate appears to determine the amount of enzyme produced by white rot Basidiomycetes fungi. 
Table 3. Estimated effects of the independent variables in the production of enzymes and proteins.

\begin{tabular}{|c|c|c|c|c|c|c|c|c|}
\hline Days & Enzymes & Parameters & Effects & Standard error & $t(2)$ & $\mathbf{p}$ & $\begin{array}{c}\text { Confidence } \\
\text { limit }(-95 \%)\end{array}$ & $\begin{array}{c}\text { Confidence } \\
\text { limit (+95\%) }\end{array}$ \\
\hline \multirow{7}{*}{6} & \multirow{4}{*}{ EG } & Media & 0.382 & 0.015 & 25.698 & 0.002 & 0.318 & 0.446 \\
\hline & & Agitation (L) & -0.172 & 0.024 & -7.281 & 0.018 & -0.274 & -0.071 \\
\hline & & pH (Q) & 0.320 & 0.036 & 8.787 & 0.013 & 0.163 & 0.477 \\
\hline & & $1 \mathrm{~L}$ by $2 \mathrm{~L}$ & 0.276 & 0.029 & 9.508 & 0.011 & 0.151 & 0.401 \\
\hline & EX & Media & 6.004 & 0.145 & 41.541 & 0.001 & 5.382 & 6.626 \\
\hline & $\beta-\mathrm{G}$ & $1 \mathrm{~L}$ by $2 \mathrm{~L}$ & -0.140 & 0.028 & -4.962 & 0.038 & -0.260 & -0.019 \\
\hline & $\mathrm{P}$ & Media & 1.754 & 0.036 & 48.828 & 0.000 & 1.599 & 1.908 \\
\hline \multirow{4}{*}{9} & EG & Media & 0.357 & 0.017 & 21.390 & 0.002 & 0.285 & 0.428 \\
\hline & & Agitation (L) & -0.122 & 0.027 & -4.595 & 0.044 & -0.236 & -0.008 \\
\hline & $\beta-\mathrm{G}$ & Media & 0.060 & 0.006 & 9.702 & 0.010 & 0.033 & 0.087 \\
\hline & $\mathrm{P}$ & Media & 1.781 & 0.023 & 78.668 & 0.000 & 1.684 & 1.878 \\
\hline \multirow{9}{*}{12} & & Agitation (Q) & 0.426 & 0.065 & 6.581 & 0.022 & 0.148 & 0.705 \\
\hline & $\mathrm{X}$ & pH (Q) & 0.340 & 0.065 & 5.242 & 0.035 & 0.061 & 0.618 \\
\hline & & $1 \mathrm{~L}$ by $2 \mathrm{~L}$ & -0.395 & 0.052 & -7.661 & 0.017 & -0.617 & -0.173 \\
\hline & & Media & 0.293 & 0.041 & 7.100 & 0.019 & 0.115 & 0.470 \\
\hline & EG & $\mathrm{pH}(\mathrm{L})$ & 0.333 & 0.066 & 5.076 & 0.037 & 0.051 & 0.616 \\
\hline & & $1 \mathrm{~L}$ by $2 \mathrm{~L}$ & -0.351 & 0.080 & -4.370 & 0.049 & -0.698 & -0.005 \\
\hline & EX & Media & 6.301 & 0.214 & 29.478 & 0.001 & 5.381 & 7.221 \\
\hline & $\beta-\mathrm{G}$ & Media & 0.079 & 0.008 & 9.846 & 0.010 & 0.044 & 0.113 \\
\hline & $\mathrm{P}$ & Media & 1.962 & 0.036 & 55.112 & 0.000 & 1.809 & 2.115 \\
\hline
\end{tabular}

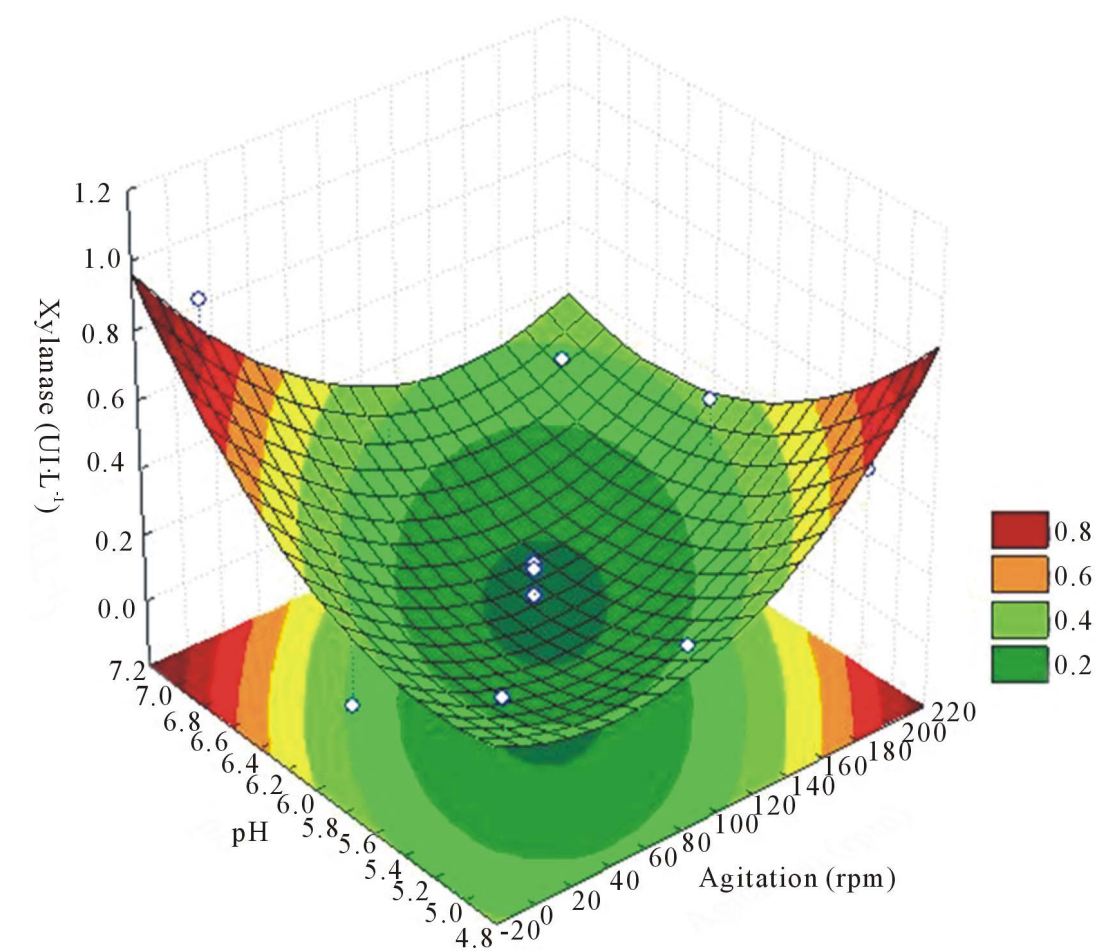

Figure 2. Response surface for purposes of agitation and different $\mathrm{pH}$ on the xylanase production at 12 days of cultivation on $L$. edodes. 


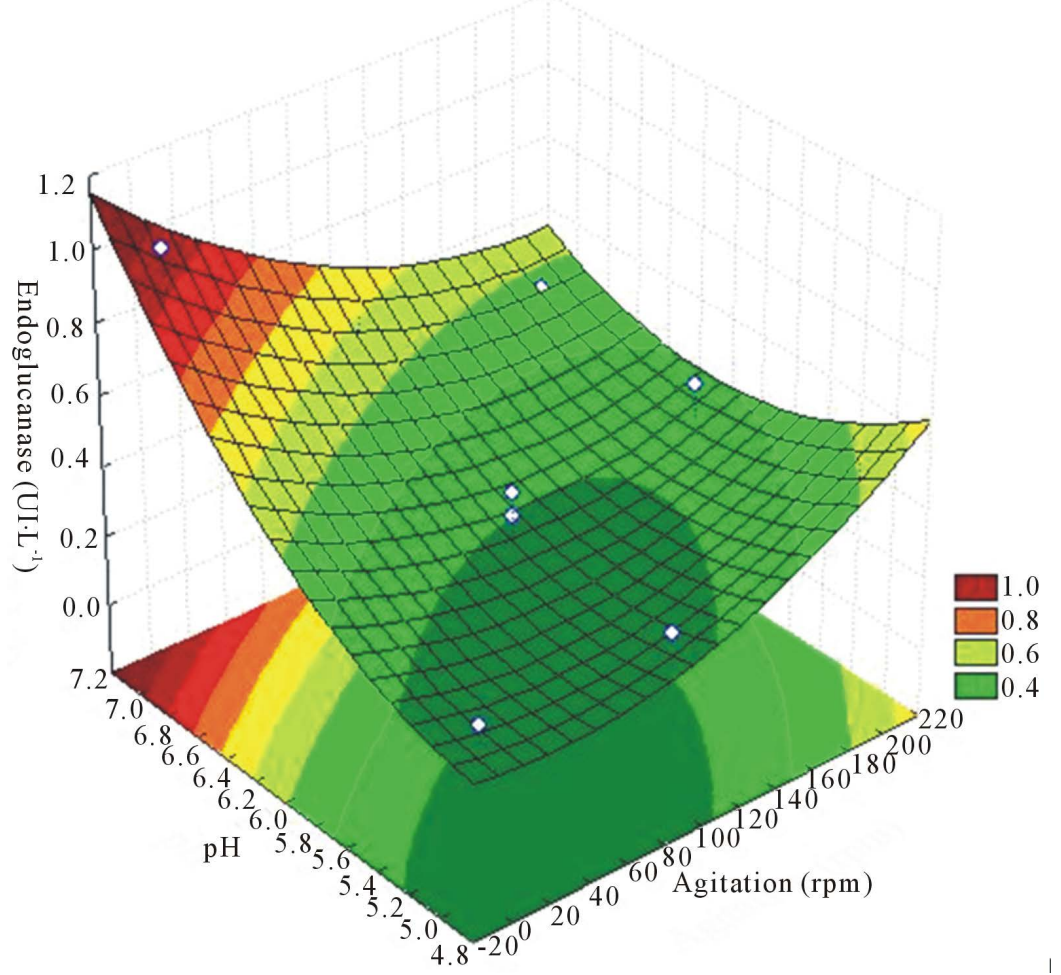

Figure 3. Response surface for purposes of agitation and different $\mathrm{pH}$ on the production of endoglucanase with 12 days of cultivation, EF for 52 strain of $L$. edodes.

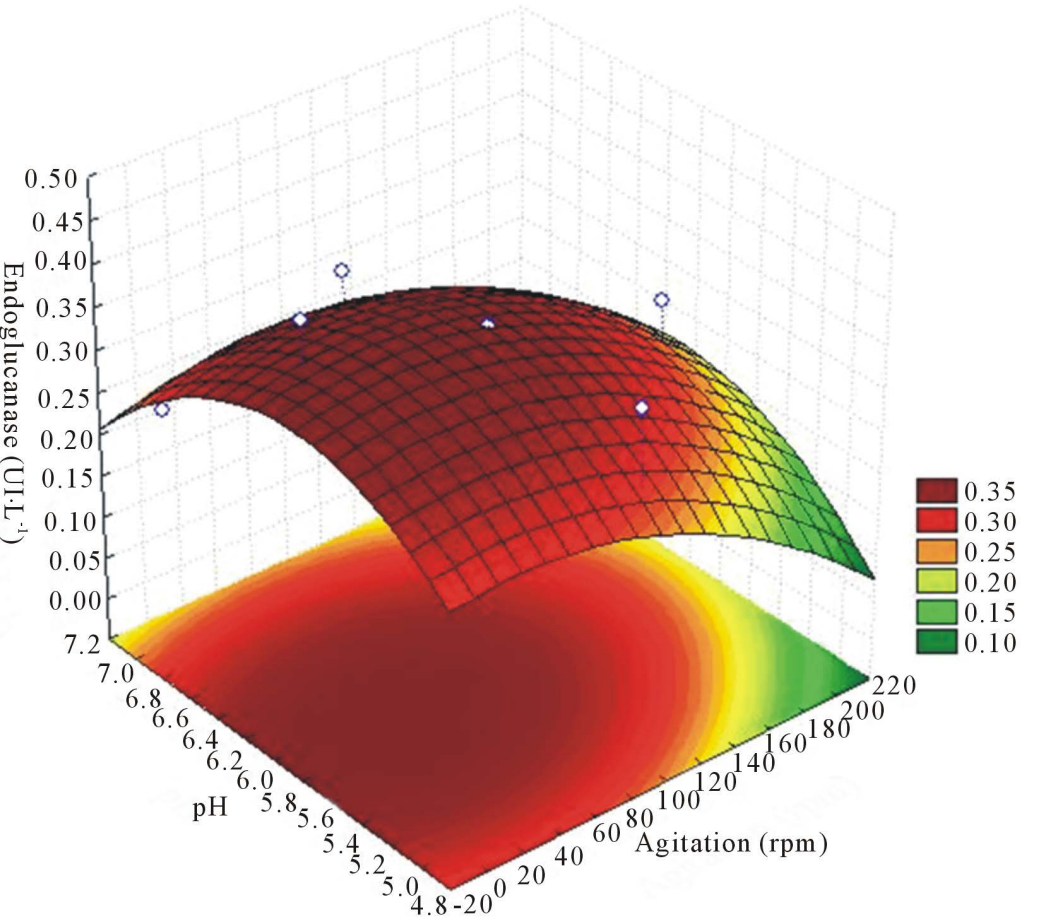

Figure 4. Response surface for purposes of agitation and different $\mathrm{pH}$ on the production of endoglucanase with 9 days of cultivation, EF for 52 strain of $L$. edodes. 
Differently from the endoglucanase, exoglucanase to the 9th day of culture produced higher enzyme activities as shown in Figure 5. For this enzyme, values closer to $\mathrm{pH} 5.0$ and agitation above $150 \mathrm{rpm}$ were the values of process variables which stood out.

For exoglucanase enzymethere happened an increase in the production, $7.97 \mathrm{UI} \cdot \mathrm{L}^{-1}$ that gave the lowest $\mathrm{pH}$ (5). Sales et al., [24] obtained the highest exoglucanase activity of $0.0017 \mathrm{UI} \cdot \mathrm{L}^{-1}$ in the low $\mathrm{pH}$ in the experiment (6).

Almeida, [23] produced and characterized cellulases and hemicellulases of the fungus Acremonium sp. in submerged culture using bagasse and obtained a higher cellulase activity at $\mathrm{pH} 6$ corroborating data from the present study.

In the study by Rodrigues [30], total cellulase showed better results at $\mathrm{pH} 4.0$, using the fungus Aspergillus niger and as a carbon source Brachiaria Brizantha.

For the enzyme $\beta$-glucosidase, activity values were very low ranging from 0.01 to $0.26 \mathrm{UI} \cdot \mathrm{L}^{-1}$, as shown in Table 2. In Figure 6, it is observed that the higher the $\mathrm{pH}$ and agitatiothe bigger the enzyme activity. On the 12th day of culture, the activity had virtually no variation independently of treatment, and the higher the $\mathrm{pH}$ and stirring, the lower the activity (Figure 7).

The highest results of the enzyme $\beta$-glucosidase, $0.12 \mathrm{UI} \cdot \mathrm{L}^{-1}$ were obtained in the shortest period of cultivation (6 days) and lower $\mathrm{pH}$ (5), [30] also found higher enzyme activity for $\beta$-glucosidase at $\mathrm{pH} 5$.

Comparing the results with the fungus Aspergillus [24] grown on sugarcane bagasse obtained $0.64 \mathrm{UI} \cdot \mathrm{L}^{-1}$, also with the lowest $\mathrm{pH}(6)$ and shorter cultivation (3 days).

Various strains and species of micro-organisms have been studied for the production of cellulases on different sources of carbon, nitrogen, $\mathrm{pH}$ and agitation. The Trichoderma reesei, one of the most studied species for the production of cellulolytic enzymes, was important for increased production of $\beta$-glucosidase. Yet, this species does not produce great quantities of $\beta$-glucosidase, which justifies the use of mixed cultures for the most efficient cellulase production [15].

For proteins, agitation and $\mathrm{pH}$ were very important variables. But the amounts of proteins had little variation (1.57 $\mathrm{mg} \cdot \mathrm{mL}^{-1}$ to $2.05 \mathrm{mg} \cdot \mathrm{mL}^{-1}$ ), regardless of the treatment and the time of culture, as seen in Table 2 . The $\mathrm{pH}$

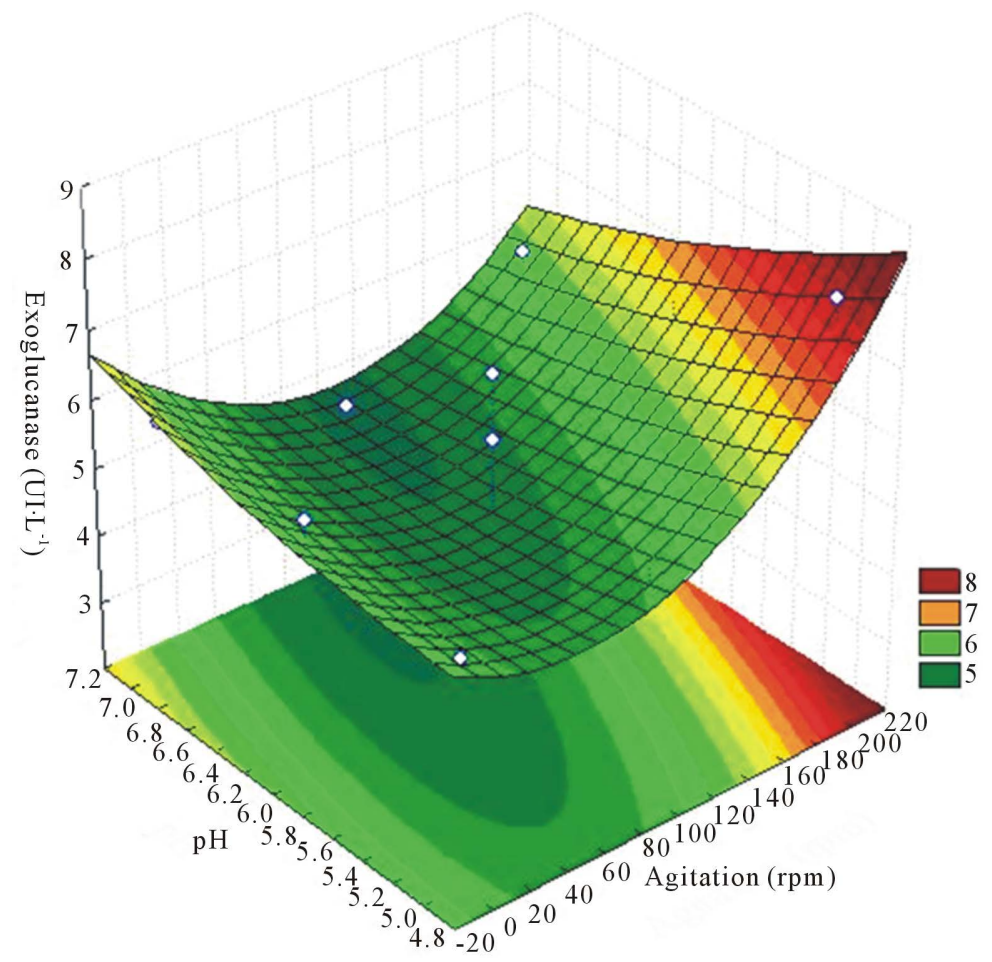

Figure 5. Response surface for purposes of agitation and different $\mathrm{pH}$ on the production of exoglucanase with 9 days of cultivation, EF for 52 strain of $L$. edodes. 


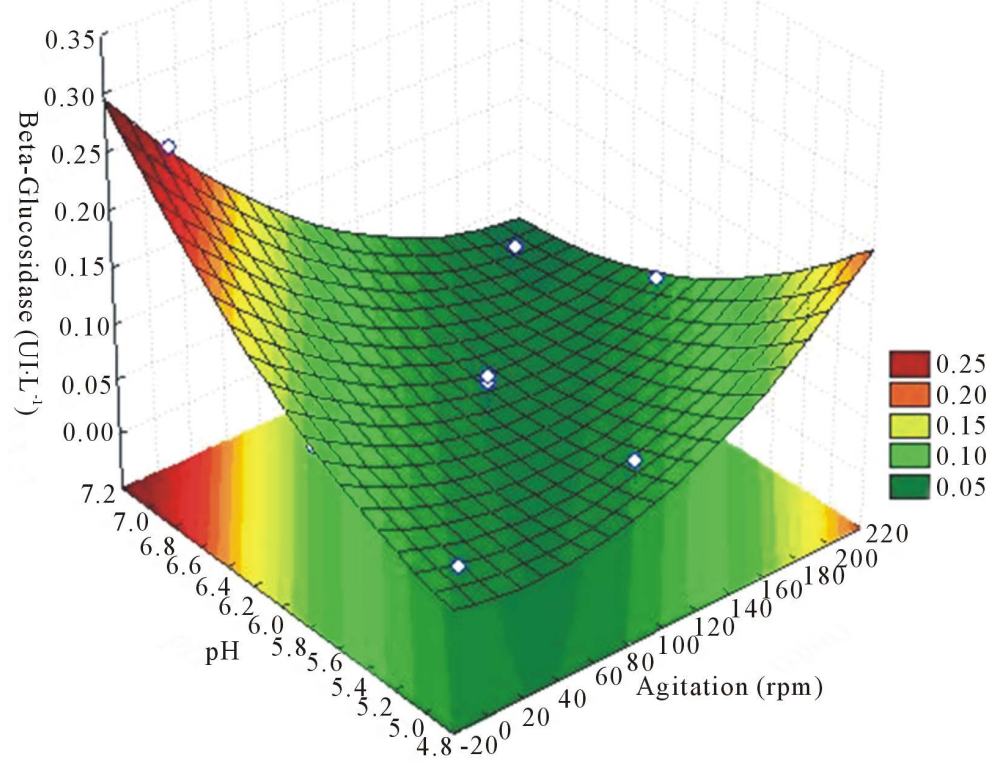

Figure 6. Response surface for the effects of agitation and different $\mathrm{pH}$ on the production of $\beta$-glucosidase with 6 days of cultivation at EF 52 strain of $L$. edodes.

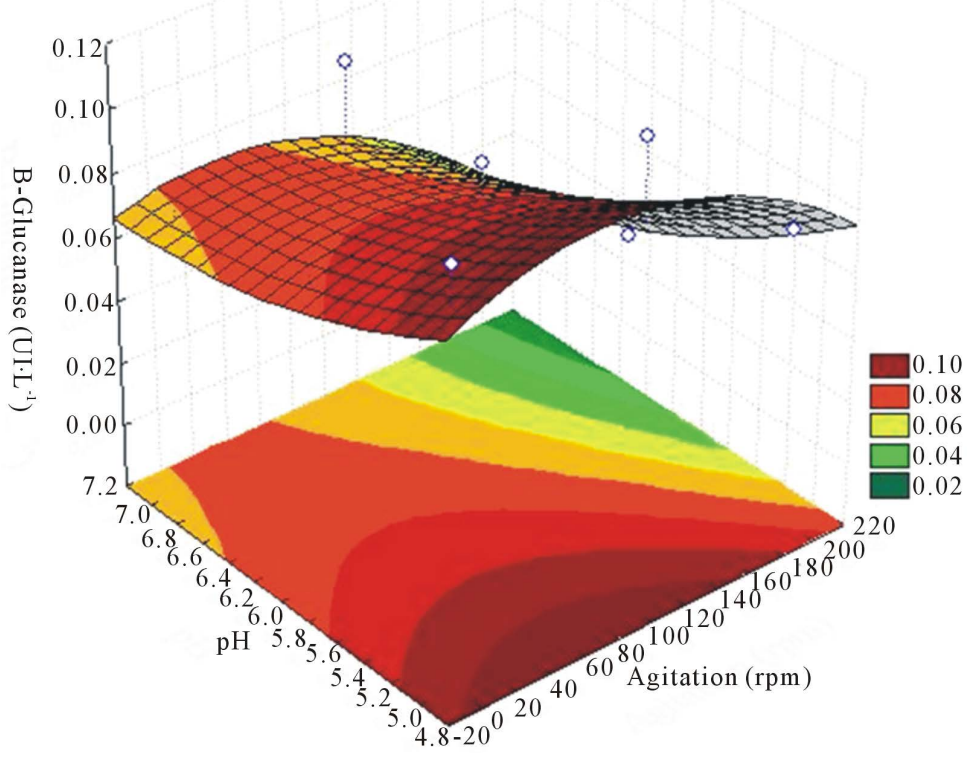

Figure 7. Response surface for the effects of different agitations and $\mathrm{pH}$ on the production of $\beta$-glucosidase, with 12 days of cultivation in the EF 52 strain of L. edodes.

did not influence the production of proteins in the sixth day of culture, unlike agitation (Figure 8). Still, the influence of $\mathrm{pH}$ was manifested after 12 days of culture (Figure 9). 


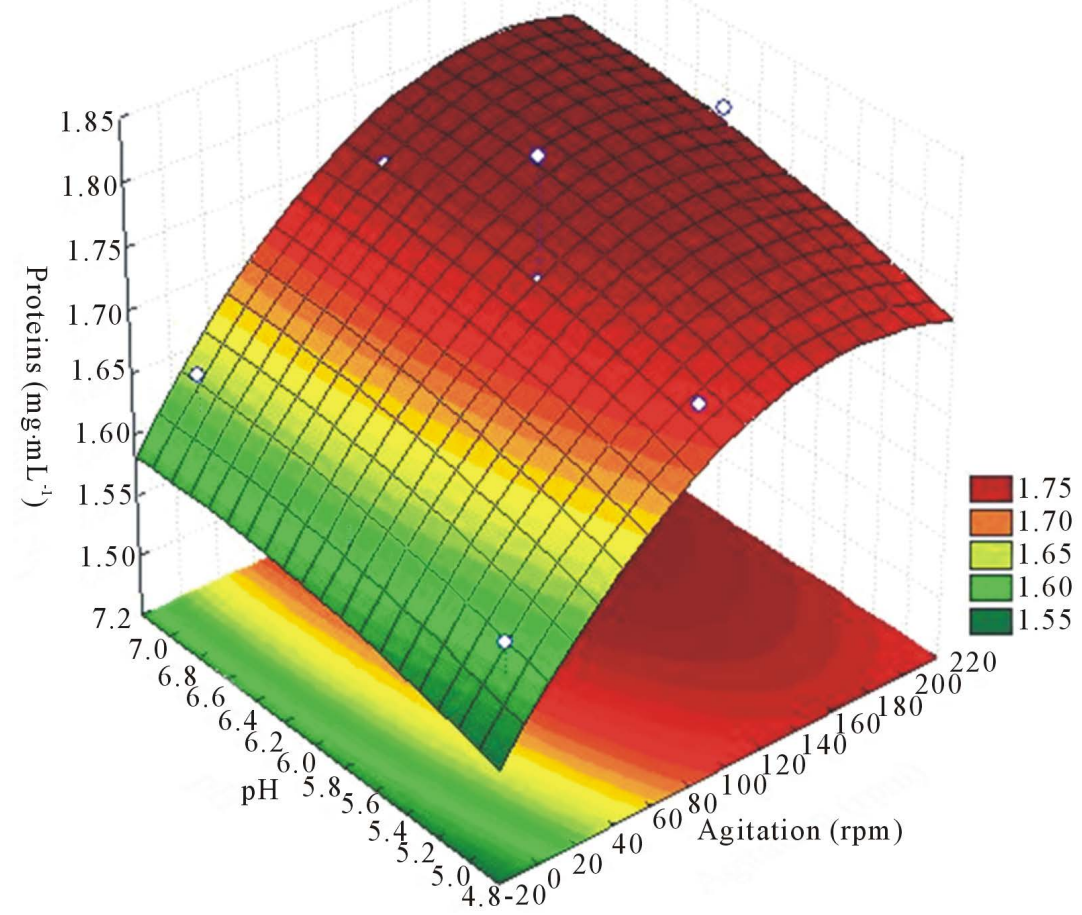

Figure 8. Response surface for purposes of agitation and different $\mathrm{pH}$ on protein production at 6 days of cultivation at EF 52 strain of $L$. edodes.

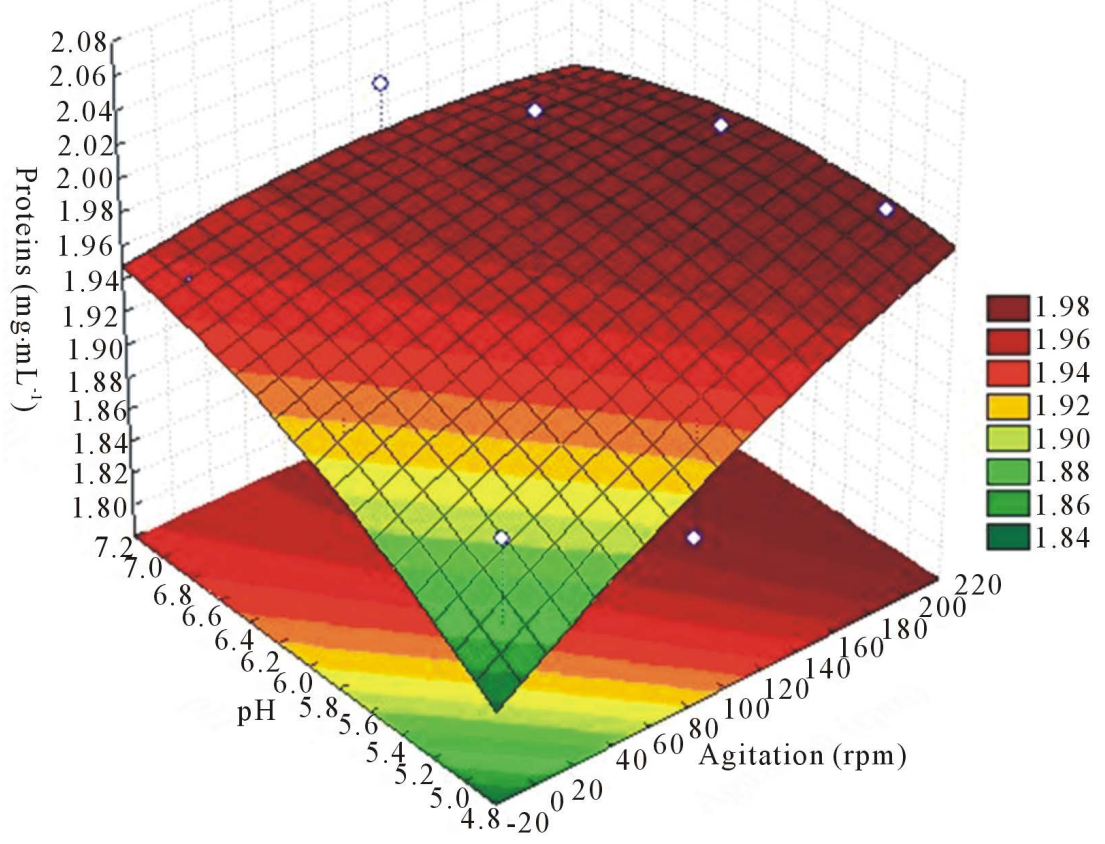

Figure 9. Response surface for purposes of agitation and different $\mathrm{pH}$ on the production of proteins with 12 days of culture at EF 52 strain of $L$. edodes. 
In studies with the L. edodes fungus [31] in solid-state fermentation, the medium had an initial pH close to 5.0, a statistically significant decrease occurring at that value after the start of growth of Lentinula. Tests used for quantification of enzyme buffer at $\mathrm{pH} 4.5$, which led to believe that $\mathrm{pH}$ values near that assist in the stability of the enzymes. Although the $\mathrm{pH}$ of the medium has fluctuated throughout the growth of the fungi was maintained between 3.6 and 4.6.

Santos et al., [32] reports that some species of basidiomycetes have a self-regulating feature of $\mathrm{pH}$ with a tendency to stabilize the value of the optimal $\mathrm{pH}$ for growth, regardless of the initial value.

The Pareto diagram demonstrates the significant effect of the variables that are highly dependent enzymes and which are being studied. In culturing for 6 days, in addition to agitation, and $\mathrm{pH}$, the linear $\mathrm{pH}$ with agitation were significant for the production of endoglucanase enzyme, Figure 10. Although the cultivation of 6 days, the linear effect of $\mathrm{pH}$ along with the agitation also showed significant effects on the production of the $\beta$-glucosidase enzyme (Figure 11).

At 9 days cultivation, the agitation was only significant for any purpose in this case to produce endoglucanase (Figure 12).

For the cultivation time of 12 days, the $\mathrm{pH}$ and the $\mathrm{pH}$ along the linear agitation were significant for the endoglucanase enzyme production (Figure 13). Regarding the production of xylanase where the $\mathrm{pH}$, agitation and interaction between these variables were also significant for the production of this enzyme (Figure 14).

\section{Conclusions}

The $\mathrm{pH}$ and agitation are important variables in the production process of enzymes. However, the $\mathrm{pH}$ values tested are within a very narrow range, compromising obtaining responses that effectively indicate the best process condition.

The $\mathrm{pH}$ is a determinant variable for the performance of enzymatic activity and, given the studied condition, the responses of enzyme activity were limited.

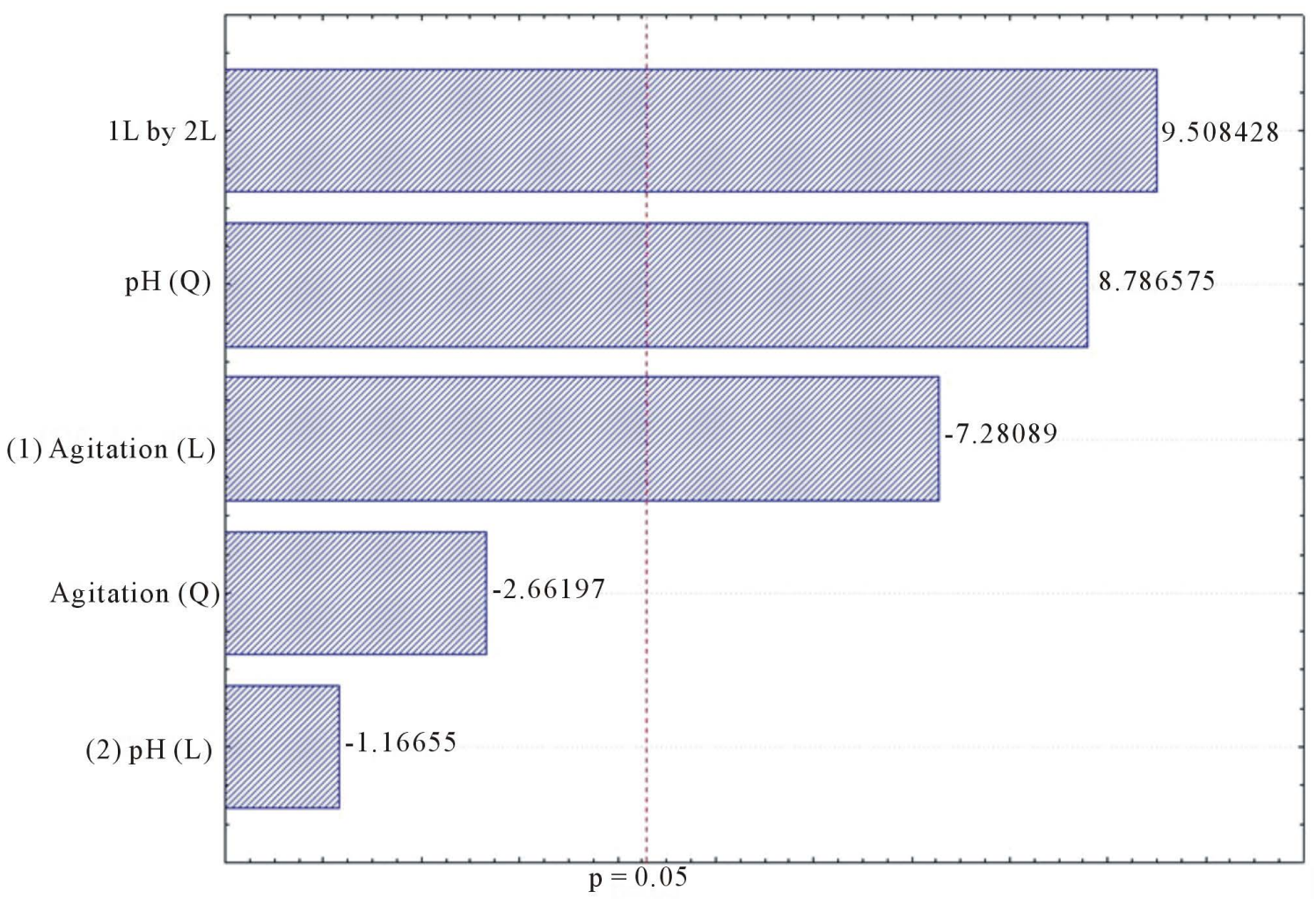

Figure 10. Pareto factorial design for the influence of stirring and $\mathrm{pH}$ on enzyme production by endoglucanase $L$. edodes with 6 days of cultivation. 


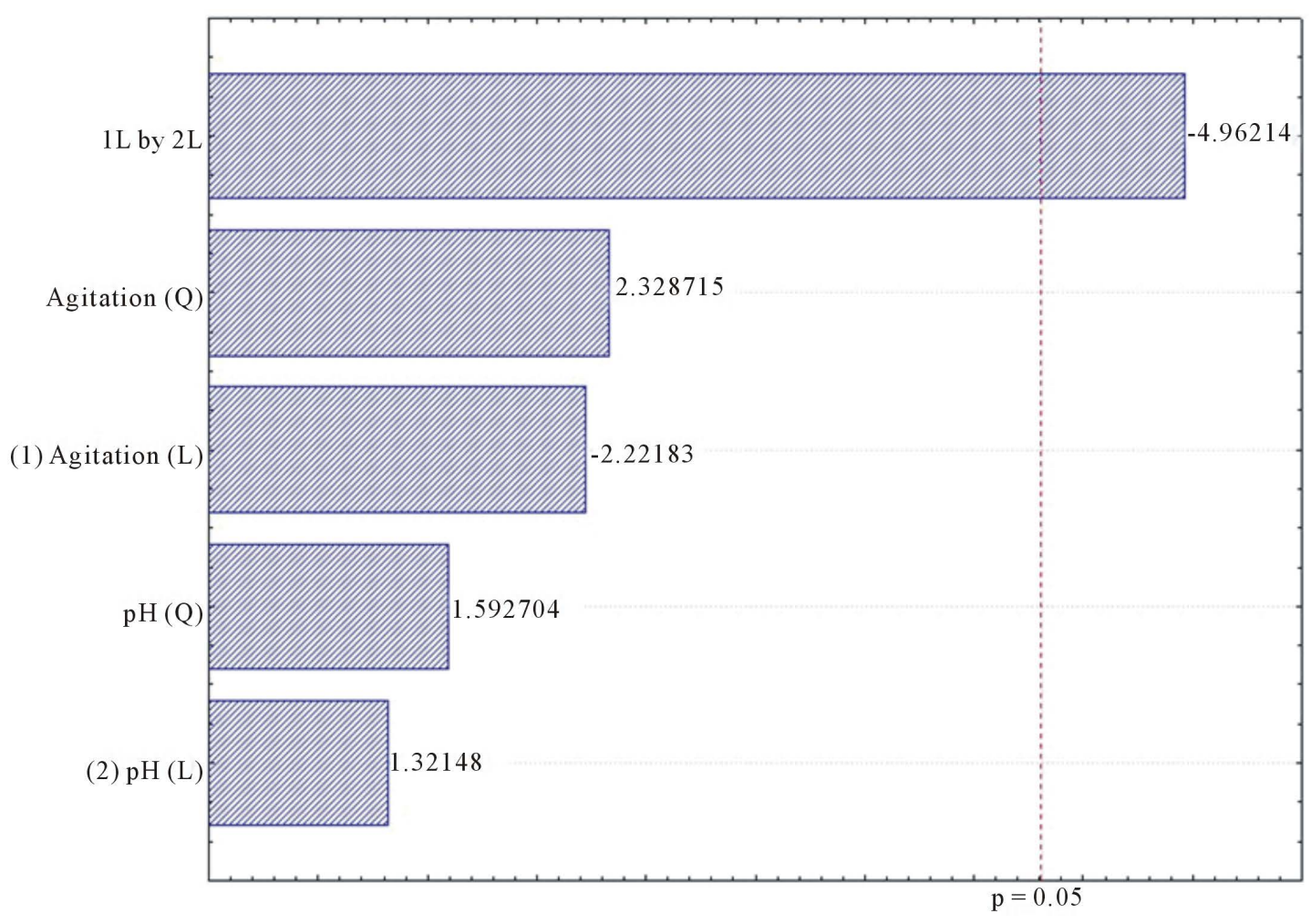

Figure 11. Pareto factorial design for the influence of $\mathrm{pH}$ and agitation in the production of the enzyme $\beta$-glucosidase by $L$. edodes with 6 days of cultivation.

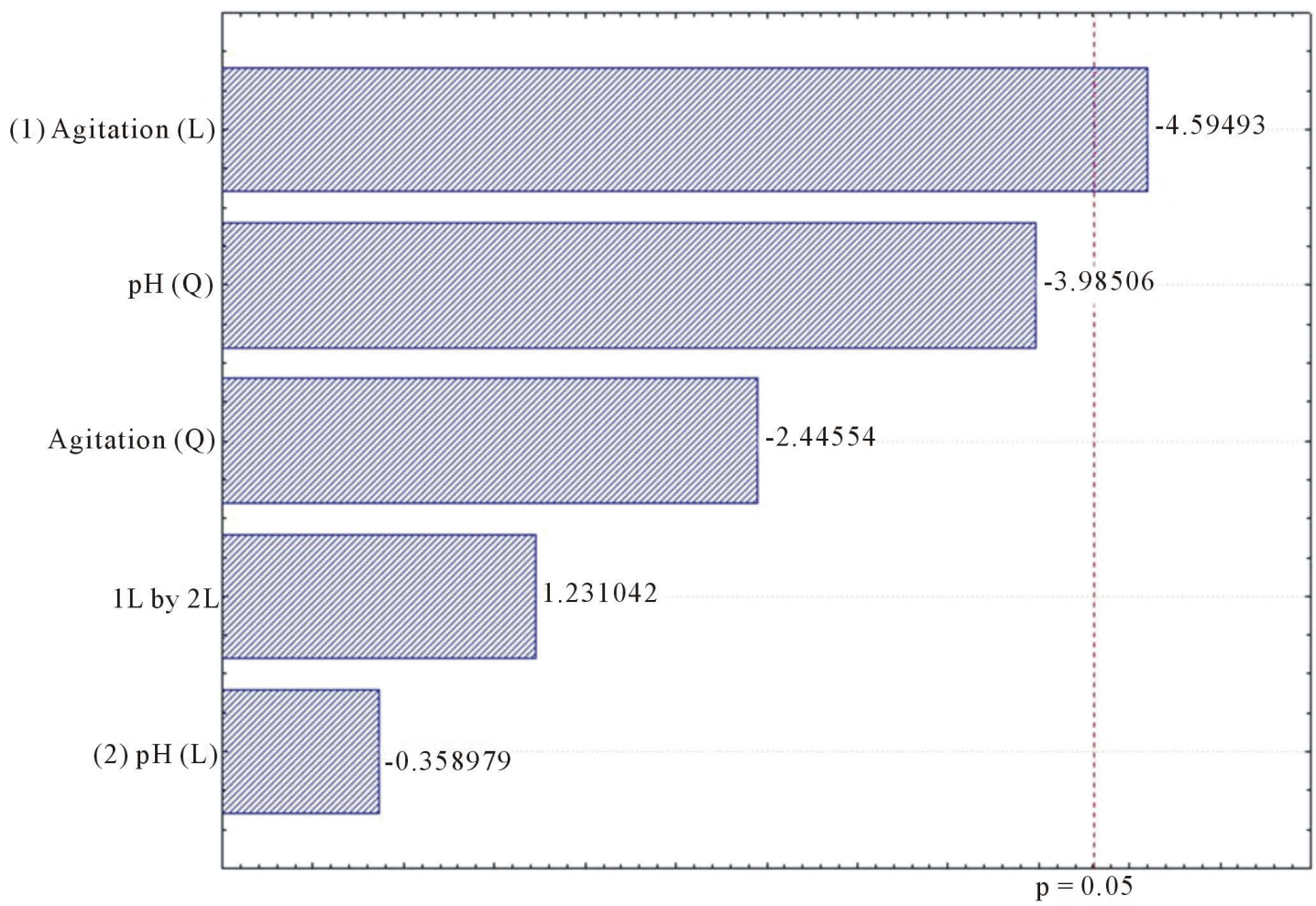

Figure 12. Pareto factorial design for the influence of stirring and $\mathrm{pH}$ on the production of endoglucanase by $L$. edodes with 9 days of culture. 


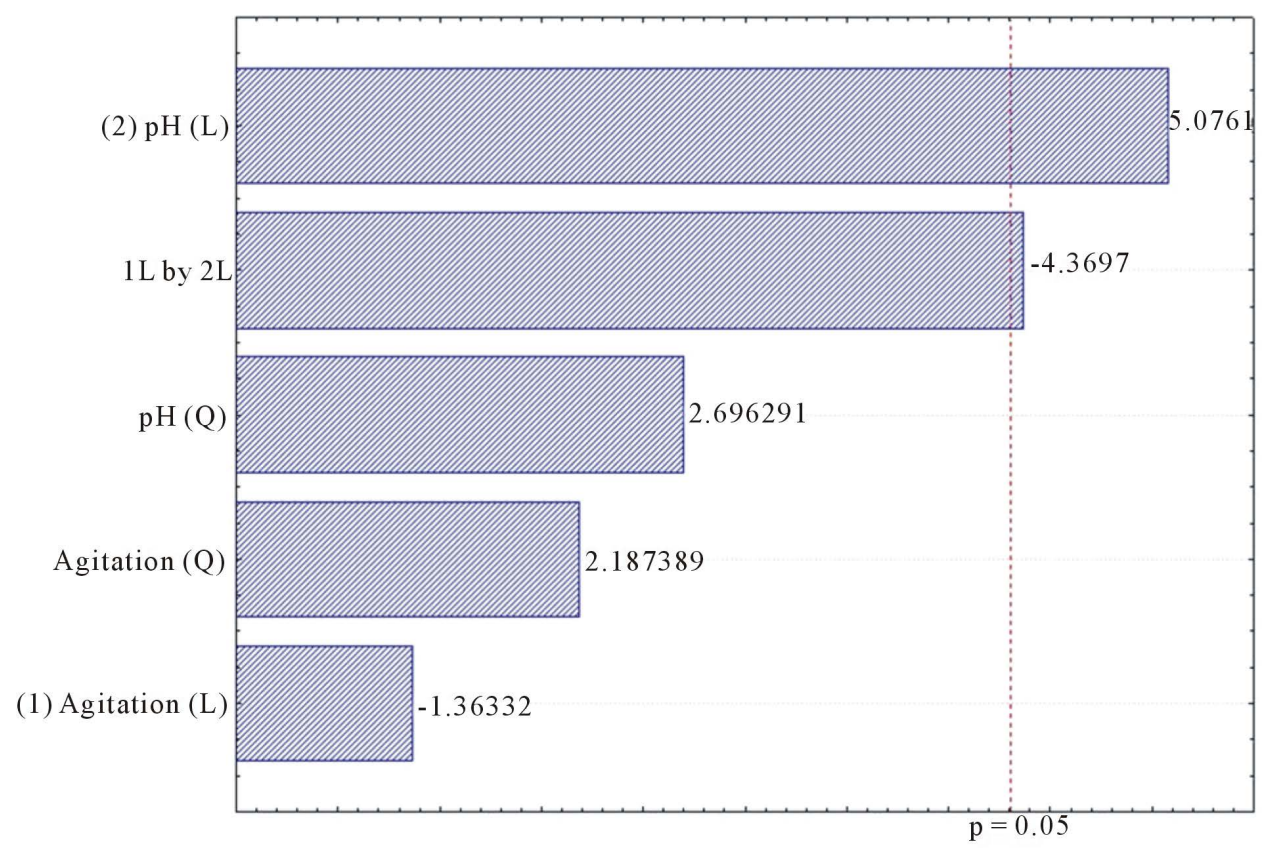

Figure 13. Pareto factorial design for the influence of stirring and $\mathrm{pH}$ on the production of endoglucanase by $L$. edodes with 12 days of cultivation.

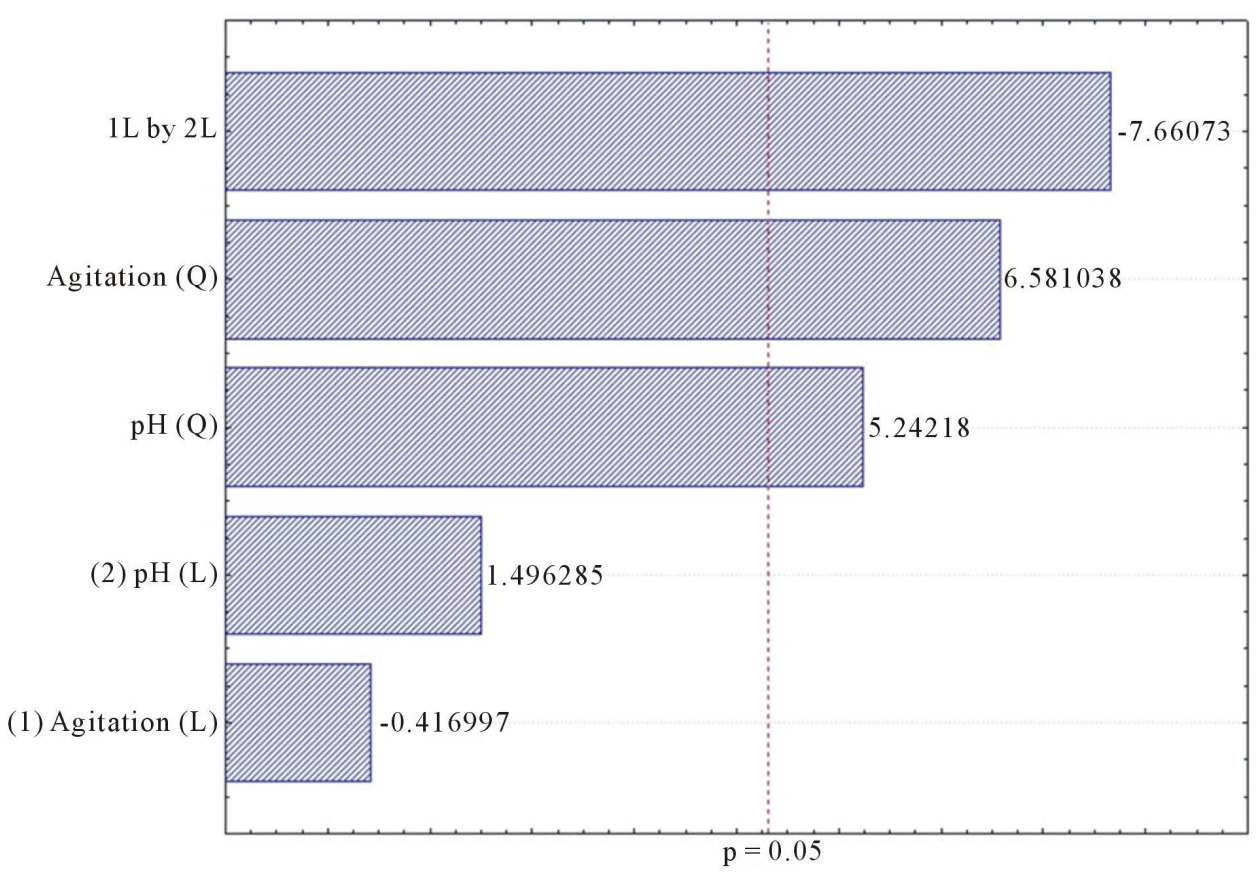

Figure 14. Pareto factorial design for the influence of stirring and $\mathrm{pH}$ on xylanase production by $L$. edodes with 12 days of cultivation.

\section{Acknowledgements}

The authors thanks the EMBRAPA Empresa Brasileira de Pesquisa Agropecuária (Brazilian Agricultural Research Corporation) CAPES, Coordenação de Aperfeiçoamento de Pessoal de Nível Superior (Coordination for Higher Education Personnal Improvement) and CNPq, Conselho Nacional de Desenvolvimento Científico e Tecnológico (National Council for Scientific and Technological Development). 


\section{References}

[1] Salihu, A., Alam, M.Z., Abdulkarim, M.I. and Salleh, H. (2012) Lipase Production: An Insight in the Utilization of Renewable Agricultural Residues. Resources, Conservation and Recycling, 58, 36-44. http://dx.doi.org/10.1016/j.resconrec.2011.10.007

[2] Pelizer, L.H., Pontieri, M.H. and Moraes, I.V. (2007) Use of Agro-Industrial Waste in Biotechnological Processes as Prospect of Reducing Environmental Impact. JOTMI, 2, 118-127.

[3] Aguiar, C.M. (2010) Enzymatic Hydrolysis of Lignocellulosic Residues Using Cellulases Produced by the Fungus Aspergillus niger. Dissertation (Masters in Chemical Engineering), University of West Paraná, Toledo.

[4] Stida, W.F., David, G.F., Ferreira, P.R. and Perez, V.H. (2012) Evaluation of Different Yeast Strains in Order to Produce Bioethanol. Fluminense Congress of Scientific and Technological Initiation, Fields Goytacazes, RJ.

[5] Margeot, A., Hahn-Hagerdal, B., Edlund, M., Slade, R. and Monot, F. (2009) New Improvements for Lignocellulosic Ethanol. Current Opinion in Biotechnology, 20, 372-380. http://dx.doi.org/10.1016/j.copbio.2009.05.009

[6] Canilha, L., et al. (2011) Saccharification of Lignocellulosic Biomass through pre Acid Hydrolysis Followed by Enzymatic Hydrolysis: A Strategy of “Deconstruction” of Plant Fiber. Analytica Journal, 38, 1476-1475.

[7] Lima, M.A. (2013) Biophysical and Biochemical Characterization of the Enzyme $\beta$-Glucosidase from Aspergillus niger BgI11 and Evaluation of Potential Biomass for Bioethanol Production. Thesis (Doctor of Science), Institute of Physics of São Carlos, University of São Paulo, São Paulo, 249 p.

[8] Pereira, V.M. (2012) Evaluation of the Enzyme Potential of Filamentous Fungi and Optimization of Cellulase Production by Aspergullis sulphureus (Fresen.) Wehmer. Dissertation (Agricultural Microbiology), Federal University of Lavras, Lavras, 112 p.

[9] Martins, L.F., et al. (2005) Perfil Hydrolytic Cellulases from Penicillium echinulatum. Proceedings of the XV National Symposium Bioprocess, Recife, 2005.

[10] Heck, J.X., Hertz, P.F. and Ayub, M.A. Z. (2002) Cellulases and Xylanase Prodution by Isolated Amazon Bacillus Strains Using Soybean Industrial Residues Based Solid-State Cultivation. Process Biochemistry, 33, 213-218.

[11] Dumitriu, S. (2005) Polysaccharides: Structural Diversity and Functional Versatility. 2nd Edition, Marcel Dekker, New York, $1204 \mathrm{p}$.

[12] Hoffmann, Z.B. (2013) Structural and Functional Studies of Hemicellulases for Potential Biotechnological Applications. Dissertation (Functional and Molecular Biology), State University of Campinas, Campinas.

[13] Heck, J.X., Hertz, P.F. and Ayub, M.A.Z. (2005) Extraction Optimization of Xylanases Obtained by Solid-State Cultivation of Bacillus circulans BL53. Process Biochemistry, 40, 2891-1895. http://dx.doi.org/10.1016/j.procbio.2005.01.006

[14] Alam, M.Z., Muyibi, S. A. and Wahid, R. (2008) Statistical Optimization of Process Conditions for Cellulase Production by Liquid State Bioconversion of Domestic Wastewater Sludge. Bioresource Technology, 99, 4709-4716. http://dx.doi.org/10.1016/j.biortech.2007.09.072

[15] Silva, F.A. (2009) Selenium in Nile Tilapia Using Gel Electrophoresis and Atomic Spectrometry. Thesis (Ph.D. in Animal Science), São Paulo State University, College of Veterinary and Animal Science, Medicine Botucatu, SP.

[16] Suárez, M., Sans, L., Chamorro, M., Rey, M., Gonzáles, F., Llobell, A. and Monte, E. (2005) Proteomic Analysis of Secreted Proteins from Trichoderma harzianum: Identification of Fungal Cell Waal-Induced Aspartic Protease. Fungal Genetics and Biology, 42, 924-934. http://dx.doi.org/10.1016/j.fgb.2005.08.002

[17] Souza, T.C., Ferreira, C.A., Brandao, P.C., Hori, C.E. and Romanielo, L.L. (2005) Evaluation of Biomass are Used as Adsorbent for the Separation of Organic Contaminants in Wastewater. Brazilian Congress of Chemical Engineering in Scientific Initiation, São Paulo, 6, 2005, 6.

[18] Bailey, M.J., Biely, P. and Poutanen, K. (1992) Interlaboratory Testing of Methods Assay of Xylanase Activity. Journal of Biotechnology, 23, 257-270. http://dx.doi.org/10.1016/0168-1656(92)90074-J

[19] Miller, G.L. (1959) Use of Dinitrosalicylic Acid Reagent for Determination of Reducing Sugar. Analytical Biochemistry, 31, 428.

[20] Tanaka, T., Taniguchi, M.A., Matsumo, R. and Kamikubo, T. (1981) Purification and Properties of Cellulases from Eupenicillium javanicium. Journal of Fermentation Technology, 59, 177-183.

[21] Wood, T.M. and Garcia-Campayo, V. (1990) Enzymology of Cellulose Degradation. International Biodeterioration and Biodegradation, 1, 147-161.

[22] Bradford, M.M. (1976) A Rapid and Sensitive Method for the Quantization of Microgram Quantities of Protein Utilizing the Principle of Protein-Dye Binding. Analytical Biochemistry, 72, 248-254.

http://dx.doi.org/10.1016/0003-2697(76)90527-3 
[23] Almeida, M.N. (2009) Characterization of Cellulases and Hemicellulases of the Fungus Acremonium zea Acremonium sp. Dissertation (Master in Agricultural Biochemistry), Federal University of Viçosa, Minas Gerais.

[24] Sales, M.R., Moura, R.B., Port, T.S., Macedo, G.R. and Porto, A.L.F. (2010) Variables that Influence the Xylanase and Cellulase Production by Aspergillus Species. Pesquisa Agropecuária Brasileira, 45, 1290-1296.

[25] Heck, J.X., Flôres, S.H., Hertz, P.F. and Ayub, M.A.Z. (2006) Statistical Optimization of Thermo-Tolerant Xylanase Activity from Amazon Isolated Bacillus circulans on Solid-State Cultivation. Bioresource Technology, 97, 1902-1906. http://dx.doi.org/10.1016/j.biortech.2005.08.013

[26] Philippoussis, A., Diamantopoulou, P., Papadopoulou, K., Lakhtar, H., Roussos, S., Parissopoulos, G. and Papanikolaou, S. (2011) Biomass, Laccase and Endoglucanase Production by Lentinula edodes during Solid State Fermentation of Reed Grass, Bean Stalks and Wheat Straw Residues. World Journal of Microbiology and Biotechnology, 27, 285297. http://dx.doi.org/10.1007/s11274-010-0458-8

[27] Silva, E.M., Machuca, A. and Milagres, A.M.F. (2005) Effect of Cereal Brans on Lentinula edodes Growth and Enzyme Activities during Cultivation on Forestry Waste. Letters in Applied Microbiology, 40, 283-288. http://dx.doi.org/10.1111/j.1472-765X.2005.01669.x

[28] Silva, E.M., Machuca, A. and Milagres, A.M.F. (2005) Evaluating the Growth and Enzyme Production from Lentinula edodes Strains. Process Biochemistry, 40, 161-164. http://dx.doi.org/10.1016/j.procbio.2003.11.053

[29] Elisashvili, V., Penninckx, M., Kachlishvili, E., Tsiklauri, N., Metreveli, E., Kharziani, T. and Kvesitadze, G. (2008) Lentinus edodes and Pleurotus Species Lignocellulolytic Enzymes Activity in Submerged and Solid-State Fermentation of Lignocellulosic Wastes of Different Composition. Bioresource Technology, 99, 457-462. http://dx.doi.org/10.1016/j.biortech.2007.01.011

[30] Rodrigues, R.M. (2009) Enzyme Production and Evaluation of Acid Biomasses for Production of Bio-Ethanol PreTreatment. Dissertation (Master in Agricultural Biochemistry), Federal University of Viçosa, Minas Gerais.

[31] Hermann, K.L. (2011) Production of Manganese Peroxidase by Lentinula boryana and Lentinula edodes Cultivated in Lignocellulosic Biomass. Dissertation (Master in Environmental Engineering), Regional University of Blumenau, Santa Catarina.

[32] Santos, V.M.C.S., Furlan, S.A., Araújo, R.P. and Gern, R.M.M. (2000) Influence of Supplementation of Rice Straw in the Production of Pleurotus Sajor-Caju. Health and Environment Journal, 1, 60-63. 